\title{
TEMPORARY EMPLOYMENT AND THE NATURAL RATE OF UNEMPLOYMENT
}

\author{
Maria Ward Otoo \\ Federal Reserve Board \\ Washington, DC 20551
}

First Draft: October 1997

Revised : July 1999

\begin{abstract}
This paper examines the determinants of the natural rate of unemployment using a combined cross section and time series data set. The results suggest that industry composition affects the natural rate. In particular, a higher share of temporary employment in a local labor market tends to lower the natural rate of unemployment--most likely through the matching function. The results suggest that the increase in the share of temporary employment may have reduced the natural rate as much as $1 / 4$ percentage point.

The results also indicate that unemployment insurance benefits tend to boost the natural rate, while having a more highly educated work force tends to lower it. However, the degree of union presence in a local labor market had little impact on the natural rate.
\end{abstract}

My thanks to helpful comments from Bruce Fallick, Charles Fleischman, Nuria RodriguezPlanas, Steven Braun and participants of the 1998 annual meetings of the American Economic Association. My thanks also to Daniel Bergstresser and Byron Lutz for valuable research assistance. The views expressed in this paper are my own and do not necessarily reflect the views of the Federal Reserve System or any of its staff. 


\section{Introduction}

The share of temporary workers ("temps") in total employment has grown rapidly in recent years. In January 1985, employees of temporary help firms accounted for 0.7 percent of total nonfarm payroll employment. By the end of 1998, this share had more than tripled to 2-1/4 percent of nonfarm employment (chart 1). ${ }^{1}$ Although many firms make use of temporary work arrangements, this paper will focus on individuals employed by temporary help (TH) agencies or leasing firms. In a TH firm, workers are paid by the agency, which sends the individual to various assignments based upon the individual's qualifications and the needs of the client. With leasing firms, the client has more of a say in who is employed; nevertheless, the leasing firm still has responsibility for the individual's pay and benefits.

The increased use of temporary employment could have broad implications for how the U.S. labor market functions. The use of temporary workers could reduce cyclical swings in labor productivity since firms might be better able to shed workers quickly during a downturn (Estevão and Lach, 1999). Similarly, there could be less of a need to hoard workers to protect against a sudden upswing in demand. Another way temporary employment could affect the labor market is by altering the way in which firms and workers are matched. Rather than searching for a job either by directly contacting firms or through some intermediary (want adds, employment agency, etc.), job seekers may accept temporary employment. If this cuts the duration of unemployment below where it otherwise would have been, this would put downward pressure on the natural rate.

This paper examines the impact that the increased use of temporary workers might have on the natural rate of unemployment. Using a combination of cross section and time series data, I find evidence that the increased use of temporary workers has lowered the natural rate of unemployment. Most likely this has occurred by quickening the match between firms and workers.

${ }^{1}$ Source: The Bureau of Labor Statistics (BLS), Current Employment Statistics (establishment) survey. Employment at temporary help firms--SIC (7363)--as a share of nonfarm payroll employment. 
The next section discusses the relationship between temporary employment and unemployment. Section 3 provides empirical support, while the final section summarizes the paper's findings and presents suggestions for future work.

\section{Temporary Employment, Unemployment Duration, and Mismatch}

Many consider the natural rate of unemployment to be the level of frictional unemployment, and it exists because matching workers to appropriate jobs takes time. It does not necessarily coincide with the NAIRU, which refers to the level of the unemployment rate consistent with a constant rate of price acceleration.

For the use of TH firms to affect the natural rate, one must assume that individuals reduce their search time from what it otherwise would have been and accept employment at the TH firm. Why would they do this? Of course, signing on at a TH firm provides the possibility of immediate employment, but one might obtain a better position with more search or by going to a standard employment agency. However, a TH firm may help to overcome information difficulties of job search. Discovering where vacancies exist and the skill requirements may not be easy because many openings are not advertised widely, if at all. In contrast, temporary help firms have a number of vacancies with different skill requirements and may be better able to make a match. In addition, TH firms may provide some degree of job training, which might be particularly attractive to new entrants or those re-entering the labor force or switching occupations. Nevertheless, an important draw of temporary employment is most likely the implicit or explicit opportunity that it provides for obtaining a permanent position with a firm. Data from the BLS reveal that the most often used method of job search is to directly approach employers -- a rather time intensive method. ${ }^{2}$ However, once inside a firm, the temporary worker may be able to obtain better information on job openings. In addition, employers can observe an individual first-hand, which may give a temp an advantage. According to the National Association of Temporary Staffing Services (NATSS) -- the trade association of the temporary help industry -- their firms are being used more and more to recruit workers for permanent slots. In a survey conducted by NATSS, 38 percent of TH workers reported that they

2 Source: Employment and Earnings (January, 1999). 
had been offered permanent employment. ${ }^{3}$ Since the survey contained only individuals still employed by the TH firm, it may significantly understate the percentage of TH workers who are offered permanent jobs.

There are a number of reasons why a company might turn to a $\mathrm{TH}$ firm to fill a vacancy. Although savings on labor costs might be considered a factor, there is little empirical support for this view. Work by Abraham and Taylor (1996) found that a variety of factors influence the use of temporary workers with direct labor costs playing a relatively minor role. Companies who use temps most often mention that convenience and flexibility matter more in their choice. Workers can be hired and fired at little direct cost to the client company. Thus, intermediation by TH firms may allow firms to fill openings more quickly since employment can be terminated just as quickly. This could cut the average duration of unemployment and lower the natural rate of unemployment.

\section{An Empirical Look at Temporary Employment and the Natural Rate}

\subsection{Using Time Series Data}

If the increased share of temporary employment in total employment has indeed improved the matching process and caused a reduction in the natural rate, the level of the unemployment rate should be cointegrated with the level of the share of temporary employment in total employment.

To examine the relationship between temporary employment and the unemployment rate at the aggregate level, I used a demographically adjusted unemployment rate (UNRDEM), which was generated by weighting the unemployment rates of difference age and sex groups by their 1965 labor force weights. ${ }^{4}$ A demographically weighted unemployment rate was used to hold constant changes in the labor force that may affect the natural rate (Perry, 1970). This allows the analysis to focus on other determinants of the natural rate. To determine the order of integration, I used the method outlined by Dickey and Pantula (1987), which indicated that the 1994.

\footnotetext{
3"Profile of the Temporary Workforce." National Association of Temporary Services,
}

${ }^{4}$ The results were invariant to the year used to weight the unemployment rates. 
demographically adjusted unemployment is I(1) over the time period under consideration. However, the share of temporary employment in total nonfarm payroll employment (TEMP) is I(2) over the same period. ${ }^{5}$ Since the two series do not share the same order of integration, it is not possible to link their levels, which would have the most information for the natural rate. Nevertheless, it is possible to see if the unemployment rate is affected by changes in industry composition. I estimated the regression shown below in which the level of the demographically adjusted unemployment rate is regressed on the share of temporary employment. The regression is "balanced" in that both the dependent and explanatory variables are I(1). I used all of the available data for the temporary help employment series, which only begins in 1982 . The regression was estimated with annual data from 1982 to 1998 . The results are shown below with the standard errors in parentheses.

$$
\text { UNRDEM }_{t}=7.93-5.41 * \triangle T E M P_{t} .
$$

The Durbin-Watson statistic from the regression in (1) was 0.48 , which is statistically significant at the five percent level, indicating that the two series are cointegrated. ${ }^{6}$

The co-integrating relationship above links the level of the unemployment rate with growth in the share of temporary employment--suggesting that an increase in growth of temporary employment lowers the average level of unemployment. This is a long-run relationship that may be partly cyclical. Nevertheless, it does suggests that changes in industry composition and not just absolute changes in employment levels can alter the unemployment

${ }^{5}$ TEMP is the ratio of nonfarm payroll employment in help supply services (SIC 7363) over total nonfarm payroll employment. Both series are from the establishment survey.

${ }^{6}$ See Engle and Granger (1987). I also performed a Dickey-Fuller test on the residuals, which confirmed that they were indeed white noise. 
rate.

\subsection{Using Combined Cross Section and Time Series Data}

To further examine the relationship between temporary employment and the natural rate of unemployment, I used a pooled data set, which contained data by metropolitan statistical areas (MSA) from 1979 to 1993. Most of the data are from the Current Population Survey (CPS). Stopping the sample at 1993 avoids any breaks in the data from the redesign on the CPS in January 1994. The data set contains 660 observations over 44 MSAs, but only the larger MSAs have observations over the entire sample period.

A pooled data set has several advantages. Using regional cross section data alone is difficult because of the limited number of observations while the time series data on temporary employment do not exhibit much variation in growth over the years (as seen in chart 1). By using the pooled data set, I hope to exploit the regional variation in unemployment rates and employment composition.

A number of specifications are available to estimate the natural rate. One could estimate a Phillips curve which would regress the unemployment rate on growth in hourly compensation. However, this specification would generate an estimate of the NAIRU - the rate of unemployment consistent with a constant growth rate in hourly compensation. Although useful, this concept does not necessarily coincide with the natural rate. Rather, I used a specification often employed in the macro literature in which the aggregate unemployment rate is assumed to contain a secular and a cyclical component modeled as:

$$
U N R_{i t}=U N R_{i t}^{*}+\beta\left(X_{i t}-E_{t-1} X_{i t}\right)+\varepsilon_{t}
$$

where UNR is the unemployment rate and UNR* is the natural rate of unemployment. The $\mathrm{i}$ subscript denotes metropolitan area, and the $t$ indicates time. The above specification splits 
movements in the unemployment rate between its secular and cyclical components. ${ }^{7}$ The unemployment rate deviates from the natural rate by the amount $\mathrm{X}_{\mathrm{t}}$ deviates from its expected value. In some specifications $\left(\mathrm{X}_{\mathrm{t}}-\mathrm{E}_{\mathrm{t}-1} \mathrm{X}_{\mathrm{t}}\right)$ is a price prediction error. It could also be the deviation of growth in gross domestic product (GDP) from its potential growth rate. To capture cyclical movements in equation (2), I chose the employment-population ratio. It can be constructed consistently with the regional data and is measured as the deviation of growth in the ratio of total wage and salary employment from the CPS relative to the civilian population in each MSA from its long-run average level $\left(E M P O P_{i t}-\overline{E M P O P_{i}}\right)$. Long-run average growth in $\left(\overline{E M P O P_{i}}\right)$ is growth in the ratio from the business cycle peak that occurred in 1981 to the next peak in 1990. In the long run, the expected value of $\left(E M P O P_{i t}-\overline{E M P O P_{i}}\right)$ is zero.

When estimated at the aggregate level, the natural rate (UNR*) is often modeled quite simply as a constant or possibly a measure of sectoral employment shifts (Lilien, 1982). Frequently with aggregate data, this is the best that can be done because of the high degree of colinearity among the variables. However, with the pooled data set, factors that affect the natural rate can be modeled explicitly. I modeled the natural rate as a linear function of the variables shown below:

$$
\begin{gathered}
\text { UNR }_{i}^{*}=f\left(\underset{j=1}{\sum} \alpha_{j} \operatorname{INDUSTRY}_{i j}, \text { SCHOOL }_{i}, U I_{i},\right. \\
\text { MINWAGE } \\
i
\end{gathered}
$$

The time subscript has been temporarily dropped. INDUSTRY ${ }_{\mathrm{ij}}$ is a series of variables representing the composition of employment in industry $\mathrm{j}$ in MSA $\mathrm{i}$. The composition of employment could have implications for the unemployment rate. ${ }^{8}$ For example, construction is often mentioned as an industry that might generate higher levels of frictional unemployment because of its higher incidence of layoff. INDUSTRY variables are discussed in greater detail a

${ }^{7}$ Additional applications of this specification can be found in Barro (1977), Lilien (1982), Abraham and Katz (1986), Gray and Spencer (1990), and Rissman (1993).

${ }^{8}$ For example, see Johnson and Layard (1986) and Blanchard and Katz (1992). 
bit later.

SCHOOL refers to the percentage of the local population that has completed at least 12 years of school and was taken from the CPS. It is included as a control for the overall skill level of the local work force. Areas with higher levels of educational attainment might be expected to have lower natural rates on the assumption that better educated workers are able to find employment more easily.

UI is a measure of expected average unemployment insurance benefits, and it was included in order to capture the income that one might expect by remaining unemployed. This is based on the assumption that unemployment insurance benefits encourage search and potentially extend the unemployment spell. The higher the benefit, the longer the jobless period is likely to be. The variable UI was created as the product: UI = expected wage*expected duration of benefits. The expected wage for each state is the average weekly wage of employed workers covered by the UI system in a given year multiplied by the state's legislated replacement ratio. If this value exceeded the states "maximum potential benefit (MPB)" then the expected wage was set equal to the MPB. ${ }^{9}$

The expected duration of benefits is the maximum number of weeks available to draw unemployment insurance benefits. In most states, this is 26 weeks; however, during periods when unemployment is high, unemployment workers may be eligible for extended benefits under a program that is funded jointly by the states and federal government. In addition, in the early 1980s and 1990s, benefits were further extended under special federal programs. One such program ran from September 1982 through March 1985 with a number of program extensions and changes over its duration. From November 1991 to February 1994, the Emergency Unemployment Compensation (EUC) program also provided unemployed workers extended benefits. The calculation of benefit duration for the UI variable took into account any extended benefits that were potentially available. Most of the data used to construct UI were obtained from the Employment and Training Administration.

${ }^{9}$ A state's maximum potential benefit is the dollar amount legislated by states that a UI recipient could potentially receive while drawing regular benefits--a time period of 26 weeks in most states. 
MINWAGE is the state's minimum wage adjusted for coverage relative to the mean minimum wage in the MSA over time. ${ }^{10}$ This allows the minimum wage to affect the natural rate in the short-run by temporarily lowering it or raising it. Boosting the minimum wage may dislocate some workers as firms adjust to the higher wage, which would temporarily boost the natural rate. However, in the long run, the minimum wage has no effect on the natural rate.

UNIONS is the percentage of employed persons covered by a union contract. This includes both union members and nonunion employees who are, nevertheless, covered under the terms of a union contract. Areas with a large union presence might have higher real wages and longer queues for union jobs.

The INDUSTRY variables control for the share in total nonagricultural wage and salary employment of six different industry groups: personnel supply services, manufacturing, construction, mining, services other than personnel supply, and public administration. All the industry data are from the CPS. The CPS roughly identifies individuals employed in personnel supply services (SIC 736), but not those working in the more narrow temporary help industry (SIC 7363). Personnel supply includes TH and leasing firms in addition to employment agencies; however, employment in help supply agencies accounts for the bulk of jobs in this sector. According to the establishment survey, temporary help supply agencies comprised 89 percent of employment in personnel supply services. If shifting the share of employment to temporary workers lowers the natural rate of unemployment, the coefficient on the share of temporary employment should be negative.

Of course, a difficulty of using CPS data to identify employment by industry is that individuals self-report. Particularly, individuals may not list personnel supply services as the industry in which they are employed. Instead, they may report the industry in which they are currently working. Data from the 1995 supplement to the CPS indicates that misreporting may be quite high. Polivka (1996) found that 56 percent of TH workers reported the industry of their client firm. The effects of this misreporting will likely lead to an understatement of the contribution of temporary employment.

Table 1 shows the means of the sample variables used in the regressions along with

${ }^{10} \mathrm{My}$ thanks to William Wascher for his data on state minimum wages over time. 
national means from published data or data constructed privately elsewhere. The purpose of the table is to provide a view of how my sample compares to published national data. The industry employment shares are shown along with national averages from the CPS; however, because there is no published series on employment in personnel supply services in the CPS, I show the national mean of this category from the establishment survey. Over the sample period, wage and salary employment in personnel supply services was 0.7 percent of total wage and salary employment--similar to the share in the establishment survey. Sample means for manufacturing, and construction also are relatively close to the national means. Mining comprises a smaller share of employment in the sample relative to the national average, which might reflect the sample's concentration in relatively large metropolitan areas. Similarly the share of services employment excluding personnel supply services was 68 percent of the sample compared to a share of 57 percent from the payroll survey. Sample means for other series in the survey are similar to their national means. Table 2 provides more detailed information on the sample's industry shares.

Table 3 shows the results of estimating equation (2) as a linear function of the variables shown in (3) plus the cyclical control $\left(E M P O P_{i t}-\overline{E M P O P_{i}}\right)$. Five of the six industry variables were included in the regression. The share of government employment was excluded. The dependent variable is the demographically adjusted unemployment rate. All of the explanatory variables were entered with a one-period lag to avoid any simultaneity bias with the exception of $\left(E M P O P_{i t}-\overline{E M P O P_{i}}\right)$. A set of yearly dummy variables was added to the model to control for cyclical or supply disturbances not adequately captured elsewhere. MSA fixed effects were added to control for unexplained variations in the unemployment rate across metropolitan areas. The error term of (2) was assumed to be independently identically distributed with a zero mean and a constant variance.

Column 1 of table 3 shows within-group estimates using fixed MSA and year effects. The coefficient on the share of temporary employment is negative and statistically significant at the 5 percent level, which supports the hypothesis that a higher share of temporary employment can lower the natural rate--presumably through its matching function.

Columns 2 through 4 of table 3 show the model estimated when state and year fixed effects are alternately dropped from the model. The fit of the model is substantially better when 
the year fixed effects are included. The coefficient on temporary employment remains significant (although it changes in size) in the various specifications. Similarly, the coefficient on the share of construction employment is negative and statistically significant in all four specifications. Although the coefficient on mining is statistically significant in column 1 , it flips sign and is insignificant when year effects are excluded.

The estimated coefficient on (MINWAGE $\left.E_{i t}-\overline{M I N W A G E_{i}}\right)$ is insignificant in the specification in column 1 and is only significant in specifications that include no year effects. This suggests that the series is capturing cyclical effects. Educational attainment and expected unemployment insurance benefits are also statistically significant.

The cyclical control $\left(E M P O P_{t}-\overline{E M P O P}\right)$ has a negative and significant coefficient. When growth in the employment-population ratio exceeds its long-run average, the unemployment rate tends to fall. The examination of the residuals of the model in column (1) revealed that they were well behaved with a constant variance and a mean of zero.

The table 4 summarizes the estimated effect of the model's explanatory variables on the natural rate of unemployment. The table shows the change in the natural rate from 1979 to 1993 resulting from the change in each variable. It is calculated by simply multiplying the change in each variable from 1979 to 1993 by its estimated coefficient shown in the first column of table 3. As seen in table 4 , the increase in temporary employment shaved about $1 / 4$ percentage point off the natural rate from 1979 to 1993, holding the shares of the other industries and other variables constant. This is a sizable contribution for such a small sector. Nevertheless, the greatest impact on the natural rate from shifting employment over the years appears to be the movement out of goods producing and into services. Educational attainment and union coverage have had little impact on the natural rate. However, the estimates also show that unemployment insurance benefits have significantly altered the natural rate--boosting it more than 1-1/2 percentage points. The large contribution from unemployment insurance can be traced to the special programs in the early 1990s that extended benefits under the EUC program. For example, in 1990, expected benefits averaged $\$ 4,183$-- a level that had remained relatively stable since 1982 . However, in 1993, expected benefits averaged $\$ 6,447$ per person, reflecting in part the effect of the EUC program. According to the model's estimates, this increase temporarily boosted the natural rate 
almost a full percentage point.

\section{Conclusion}

This paper has examined some of the determinants of the natural rate of unemployment using a combined cross section and time series data set. The results suggest that industry composition is important. In particular, it finds support for the likelihood that the increased use of temporary workers has lowered the natural rate of unemployment, which is consistent with the results in Katz and Krueger (1999). One way that temporary workers could lower the natural rate is through the matching function. An area of future research might be to examine if individuals who exit unemployment into temporary employment have shorter spells of unemployment than do other job seekers.

It also found other factors had a significant impact on the natural rate over time. In particular, unemployment insurance benefits appear to have temporarily (but significantly) raised the natural rate in the early 1990s. In addition, the shift of jobs out of the goodsproducing sector and into services over the past two decades also boosted the natural rate. However, the decline in unionization in recent years exerted only small downward pressure on the natural rate. 
Table 1

\section{SAMPLE AND NATIONAL MEANS OF REGRESSION VARIABLES \\ (Averages from 1979 to 1993 )}

\begin{tabular}{|c|c|c|}
\hline Variable: & Sample Means & National Mean \\
\hline Share of personnel supply employment & 0.7 percent & 1 percent $^{2}$ \\
\hline Share of manufacturing employment & 19 percent & 20 percent \\
\hline Share of construction employment & 6 percent & 4 percent \\
\hline Share of mining employment & 0.4 percent & 0.9 percent \\
\hline $\begin{array}{l}\text { Share of services excluding temporary employment } \\
\text { and public administration }\end{array}$ & 68 percent & 57 percent $^{2}$ \\
\hline Share of public administration employment & 5 percent & 5 percent \\
\hline Share of work force with 12 or more years of school & 76 percent & 72 percent $^{3}$ \\
\hline Share of employment covered by a union contract. & 25 percent & 21 percent \\
\hline Maximum expected potential UI benefit & $\$ 4,146^{1}$ & n.a. \\
\hline Minimum wage (adjusted for coverage) & $\$ 3.0$ per hour & $\$ 2.7$ per hour \\
\hline Demographically adjusted unemployment rate & 7 percent & 7 percent \\
\hline
\end{tabular}

Note: Data are from the Current population survey except where noted otherwise. The sample means are from a sample with 660 observations over 44 MSAs from 1979 to 1993. Employment is presented as a share of nonagricultural wage and salary employment (excluding workers in private households). Source: Bureau of Labor Statistics.

1. Derived from data from the Employment and Training Administration, U.S. Department of Labor.

2. Current Employment Statistics (establishment) survey. Source: Bureau of Labor Statistics.

3. Share of noninstitutional population age 25 and over with twelve years or more of school. 
Table 2

Variation of Sample Industry Shares

(Annual data 1979-1993)

\begin{tabular}{|lcccc|}
\hline $\begin{array}{l}\text { Variable } \\
\text { (Percent) }\end{array}$ & Mean & $\begin{array}{c}\text { Standard } \\
\text { Deviation }\end{array}$ & Minimum & Maximum \\
\hline Personnel supply & 0.67 & 0.37 & 0 & 2.1 \\
Mining & 0.42 & 1.0 & 0 & 6.3 \\
Construction & 6.2 & 1.6 & 2.4 & 14.8 \\
Government & 5.0 & 3.3 & 1.2 & 22.6 \\
Services excluding temporary & 68.4 & 5.4 & 47.8 & 79.6 \\
Manufacturing & 19.3 & 7.1 & 4.2 & 41.2 \\
\hline
\end{tabular}

Note: Share of nonagricultural wage and salary employment in the sector indicated (excluding private households). The sample consists of 660 observations over 44 MSAs. Data are from the CPS. 
Table 3

WITHIN-GROUP ESTIMATES OF THE EFFECTS OF Temporary EMPLOYMENT ON THE NATURAL RATE OF UNEMPLOYMENT

\begin{tabular}{|c|c|c|c|c|}
\hline & $(1)$ & $(2)$ & (3) & $(4)$ \\
\hline TEMPORARY $_{\mathrm{t}-1}$ & $\begin{array}{c}-.57 * * \\
(.23)\end{array}$ & $\begin{array}{c}-1.32 * * \\
(.24)\end{array}$ & $\begin{array}{c}-.61 * * \\
(.22)\end{array}$ & $\begin{array}{c}-1.33 * * \\
(.24)\end{array}$ \\
\hline MANUFACTURE $_{\mathrm{i},-1}$ & $\begin{array}{l}-.12 \\
(.08)\end{array}$ & $\begin{array}{l}-.08 \\
(.09)\end{array}$ & $\begin{array}{l}-.13 \\
(.07)\end{array}$ & $\begin{array}{l}-.09 \\
(.08)\end{array}$ \\
\hline CONSTRUCTION $_{\mathrm{i},-1-1}$ & $\begin{array}{r}-.22 * * \\
(.09)\end{array}$ & $\begin{array}{c}-.43 * * \\
(.10)\end{array}$ & $\begin{array}{c}-.25^{* *} \\
(.09)\end{array}$ & $\begin{array}{c}-.44 * * \\
(.10)\end{array}$ \\
\hline MINING $_{\mathrm{i}, \mathrm{t}-1}$ & $\begin{array}{l}-.39 * \\
(.22)\end{array}$ & $\begin{array}{l}.27 \\
(.25)\end{array}$ & $\begin{array}{l}-.37^{*} \\
(.22)\end{array}$ & $\begin{array}{l}.28 \\
(.24)\end{array}$ \\
\hline SERVICES $_{\mathrm{i}, \mathrm{t}-1}$ & $\begin{array}{l}-.09 \\
(.07)\end{array}$ & $\begin{array}{c}-.13^{* *} \\
(.08)\end{array}$ & $\begin{array}{l}-.11 \\
(.07)\end{array}$ & $\begin{array}{l}-.14^{*} \\
(.08)\end{array}$ \\
\hline$\left(M I N W A G E_{i}-\overline{M I N W A G E_{i}}\right)_{t-1}$ & $\begin{array}{l}-.22 \\
(.13)\end{array}$ & $\begin{array}{l}.42 * * \\
(.09)\end{array}$ & $\begin{array}{l}-.09 \\
(.14)\end{array}$ & $\begin{array}{l}.54^{* *} \\
(.10)\end{array}$ \\
\hline$(E M P O P-\overline{E M P O P})_{i t}$ & $\begin{array}{c}-.17 * * \\
(.02)\end{array}$ & $\begin{array}{c}-.15^{* *} \\
(.02)\end{array}$ & $\begin{array}{c}-.17 * * \\
(.02)\end{array}$ & $\begin{array}{c}-.15^{* *} \\
(.02)\end{array}$ \\
\hline $\mathrm{SCHOOL}_{\mathrm{i},-1}$ & $\begin{array}{c}-.19 * * \\
(.03)\end{array}$ & $\begin{array}{c}-.32 * * \\
(.03)\end{array}$ & $\begin{array}{c}-.20 * * \\
(.03)\end{array}$ & $\begin{array}{c}-.32 * * \\
(.03)\end{array}$ \\
\hline $\mathrm{UNION}_{\mathrm{i}, \mathrm{t}-1}$ & $\begin{array}{l}.01 \\
(.01)\end{array}$ & $\begin{array}{l}.02 * * \\
(.01)\end{array}$ & $\begin{array}{l}.01 \\
(.01)\end{array}$ & $\begin{array}{l}.02 * * \\
(.01)\end{array}$ \\
\hline EXP_UI ${ }_{i, t-1}$ & $\begin{array}{l}.0004^{* * *} \\
(.0001)\end{array}$ & $\begin{array}{l}.0004 * * \\
(.0001)\end{array}$ & $\begin{array}{l}.0004^{* *} \\
(.0001)\end{array}$ & $\begin{array}{l}.0004 * * \\
(.0001)\end{array}$ \\
\hline Adjusted $\mathrm{R}^{2}$ & .51 & .32 & .54 & .37 \\
\hline Year effects & Yes & No & Yes & No \\
\hline State effects & Yes & Yes & No & No \\
\hline
\end{tabular}

Note: The dependent variable is a demographically adjusted unemployment rate. Standard errors are in parentheses. A* indicates significance at the 10 percent level, while ** indicates significance at the 5 percent level. The sample contains 660 observations from 44 MSAs from 1979-1993. MANUFACTURE,

CONSTRUCTION, refers to the share of employment in the respective industries. TEMPORARY is the share of employment in personnel supply services. MINWAGE is the ratio of the minimum wage, adjusted for coverage and divided by the average wage in the locale. EMPOP is the local ratio of employment to the civilian population. SCHOOL is the proportion of the work force that completed at least 12 years of school. UNION is the share of employment covered by a union contract. UI is the expected unemployment benefit. Data on employment, unemployment, population, school attainment, and unionization are from the Current Population Survey published by the BLS. Data used to construct expected unemployment insurance benefits was provided by the Employment and Training Administration of the Department of Labor. 
Table 4

Impact on the Natural Rate of Unemployment (Change from 1979 to 1993; percentage points)

\begin{tabular}{|lc|}
\hline Change in: & Natural Rate \\
\hline Share of temporary employment & -0.28 \\
Share of manufacturing employment & .90 \\
Share of construction employment & 0.10 \\
Share of service employment (excluding personnel supply) & -0.77 \\
Share of mining employment & -0.07 \\
Share of population with 12 years or more of school & -0.02 \\
Share of employment covered by a union contract & -0.08 \\
Expected unemployment insurance benefits & 1.63 \\
\hline
\end{tabular}

Note: The contribution to the change in the natural rate is the change in the series from 1979 to 1993 multiplied by the estimated coefficient in table 3, column 1. 


\section{REFERENCES}

Abraham, K. G. and Katz, L. F. (1986), "Cyclical Unemployment: Sectoral Shifts or Aggregate Disturbances," Journal of Political Economy, 94: 507-522.

Abraham, K. G. and Taylor, S. (1996), "Firms Use of Outside Contractors: Theory and Evidence," Journal of Labor Economics, 14: 394-424.

Barro, R. J. (1977), "Unanticipated Money Growth and Unemployment in the United States," American Economic Review, 67: 101-115.

Bureau of Labor Statistics (January, 1997). Employment and Earnings, 44, Department of Labor.

Dickey, D. A. and Pantula, S. G. (1987), "Determining the Order of Differencing in Autoregressive Processes," Journal of Business and Economic Statistics, 15: 455-461.

Engle, R. F. and Granger, C. W. J. (1987), "Co-integration and Error Correction: Representation, Estimation and Testing," Econometrica, 55: 251-276.

Estevão, M. and Lach, S. (1999), "Measuring Labor Outsourcing in U.S. Manufacturing." Mimeo.

Gray, J. and Spencer, D. (1990), "Price Prediction Errors and Real Activity: A Reassessment," Economic Inquiry, 28: 658-681.

Katz, L. F. and Krueger, A. B. (1999), "The High-pressure U.S. Labor Market of the 1990s," Brookings Papers on Economic Activity, Macroeconomics: 1.

Lilien, D. M. (1982), "Sector Shifts and Cyclical Unemployment," Journal of Political Economy, 90: 777-793.

Perry, G. L. (1970), "Changing Labor Markets and Inflation," Brookings Papers on Economic Activity, 3: 411-441.

Polivka, A. (1996), "Are Temporary Help Workers Substitutes for Direct Hire Temps? Searching for an Alternative Explanation of Growth in the Temporary Help Industry." Mimeo.

Rissman, E. (1993), "Wage Growth and Sectoral Shifts: Phillips Curve Redux." Journal of Monetary Economics, 31: 395-416. 
JOBS AT TEMPORARY HELP AGENCIES AS A SHARE OF TOTAL EMPLOYMENT

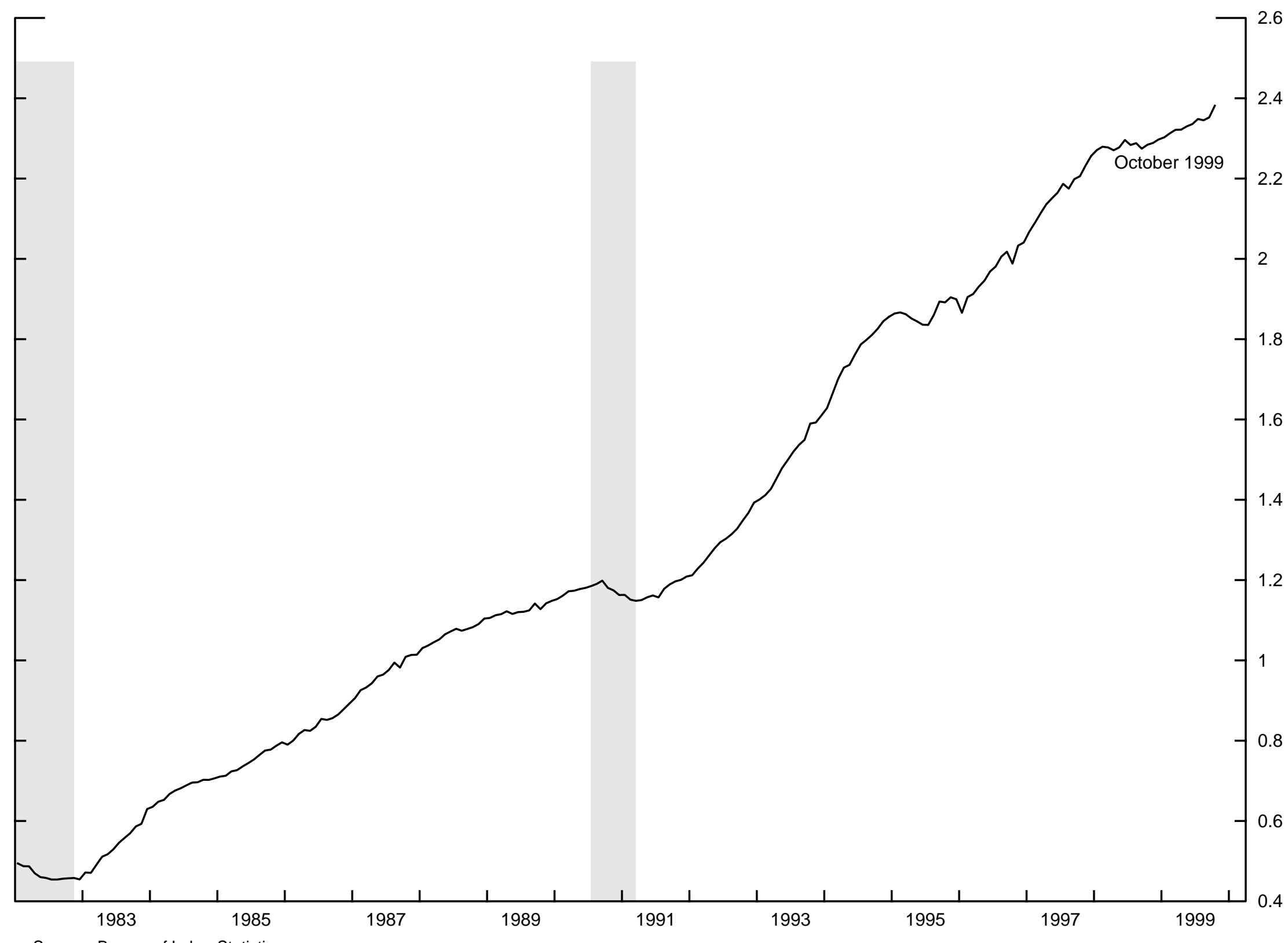

Source: Bureau of Labor Statistics. 